\title{
UNJUK KERJA REFLEKTOR RADIASI PANAS DENGAN 1 BARIS SIRIP TERHADAP EFISIENSI KOMPOR LPG
}

\author{
Sudarno ${ }^{1}$, Sudjito Soeparman ${ }^{2}$, Slamet Wahyudi ${ }^{2}$, Agung Sugeng Widodo ${ }^{2}$ \\ ${ }^{1}$ Program Studi Teknik Mesin Fakultas Teknik, Universitas Muhammadiyah Ponorogo \\ Jl. Budi Utomo No. 10 Ponorogo \\ ${ }^{2}$ Program Studi Teknik Mesin Fakultas Teknik Universitas Brawijaya Malang \\ Jl. Mayjend. Haryono No. 167 Malang \\ Telp. (0352) 481124 Fax. (0352) 461796 Email : darnotec_umpo@yahoo.co.id
}

\begin{abstract}
It has been known from the previous researchers that the use of the heat radiation reflector can improve the efficiency of the LPG stoves. Based on the radiation theory, the radiation energy is emitted radially in all directions. Therefore, a kind of method to guide the heat radiation is required to minimize the heat losses. One of the method is to add some fins to the reflector in order to capture the potential heat loss from the non-finned reflector. In this work, we use one fin line reflector made from a plate of stainless steel in the shape of cuttedcone. The boiling water test is used to investigate the efficiency of LPG stoves. We find that the efficiency of LPG stoves can be increased by adding one fin line reflector by about $5.21 \%$ and $1.75 \%$ than that one without reflector and non-finned reflector, respectively. The result of the temperature distribution shows that one fin line reflector enlarge the area of complete combustion.
\end{abstract}

Keywords: LPG stoves, one fin line reflector, efficiency

\section{PENDAHULUAN}

Panas radiasi yang terbuang dari api ke sekeliling, merupakan salah satu penyebab rendahnya efisiensi kompor LPG. Hal ini disebabkan adanya beda temperatur yang tinggi antara dinding api dengan lingkungan, pada jarak antara head burner dengan beban. Oleh karena itu transfer panas ke lingkungan merupakan losses yang harus diupayakan seminimal mungkin. Berdasarkan hasil penelitian sebelumnya, ada dua cara dalam meningkatkan efisiensi kompor LPG, yaitu rekayasa konstruksi dan optimalisasi pemanfaatan api.

Upaya rekayasa konstruksi telah banyak dilakukan, yaitu [9] penggunaan brass sebagai material head burner dapat meningkatkan efisiensi termal sebesar $4 \%$ dan desain flat face pada head burner dapat meningkatkan efisiensi sebesar $10 \%$. Selanjutnya [1], menemukan bahwa penggunaan porous ceramic doped with rare earth elements (PCR), mampu merubah warna nyala dari merah ke biru. Ditemukan pula adanya penurunan konsentrasi $\mathrm{CO}$ dan $\mathrm{O}_{2}$ pada gas buang, masing-masing $40,9 \%$ dan 12,8\%. Penggunaan Porous Radiant Burners (PRB) dapat meningkatkan efisiensi sebesar $10 \%$ dan api lebih stabil [8]. Mishra (2015) menggunakan Two-Layer Porous Radiant Burner, pada daerah pembakaran menggunakan Silicon Carbon (SiC) dan pada daerah preheating menggunakan alumina[7]. Diperoleh bahwa distribusi temperatur radial hampir uniform, efisiensi termal meningkat dari $45 \%$ menjadi $58 \%$, emisi CO dan NOx turun signifikan.

Namun upaya optimasi pemanfaatan api baru beberapa penelitian, diantaranya Syarial (2012) menemukan bahwa efisiensi termal kompor biogas meningkat sebesar $5.6 \%$ dengan penggunaan reflektor panas berlubang berdiameter $10 \mathrm{~mm}[13]$. Selanjutnya Wardani (2007) menemukan bahwa pemanfaatan alat pengumpul aliran gas dari aluminium mampu meningkatkan efisiensi sebesar $10 \%$ dibandingkan dengan kompor gas standar[16]. Diperkuat oleh Gohil (2011) menyatakan bahwa dengan penggunaan selubung untuk menutup ruang bakar mampu meningkatkan eifisiensi termal pada kompor gas sebesar $66.27 \%$ dan panas yang dihasilkan sebesar 1.7849 $\mathrm{kW}[3]$.

Mishra (2015) menemukan bahwa penggunaan keramik sebagai material reflektor pada kompor gas dapat 
meningkatkan efisiensi sebesar $2,6 \%$, yaitu sebesar 46,36\%[17]. Selanjutnya Widodo (2016) menemukan bahwa penambahan material grid (material inserting) diantara burner dan loading dapat meningkatkan efisiensi kompor LPG[19]. Efisiensi tertinggi sebesar $58.8 \%$ diperoleh pada grid dengan tebal $5 \mathrm{~mm}$. Widodo (2015) juga menemukan bahwa loading height pada kompor gas mempengaruhi efisiensi yang dihasikan[18]. Loading height optimal terjadi pada $4 \mathrm{~mm}$, dengan laju alian massa 0,0125 liter/detik. Hal serupa ditemukan oleh Sudarno (2016) bahwa tinggi beban optimal sebesar $35 \mathrm{~mm}$ dengan efisiensi sebesar 53.39\%[10].

Berdasarkan penelitian tersebut bahwa dengan reflektor, losses panas kelingkungan dapat direfleksikan kembali ke daerah pembakaran dan ke beban sehingga menjadi energi berguna. Upaya peningkatan efisiensi menggunakan reflektor masih dapat dilakukan, yaitu dengan menambahkan sirip-sirip pada reflektor. Sirip-sirip ini berfungsi menangkap losses panas yang tidak dapat ditangkap oleh reflektor tanpa sirip, mengingat panas radiasi dipancarkan ke segala arah. Upaya ini yang belum dilakukan peneliti sebelumnya.

Tujuan penelitian ini adalah menemukan pengaruh reflektor panas bersirip terhadap peningkatan efisiensi dan distribusi temperatur pada kompor LPG. Penelitian ini baru menampilkan sebagian dari tahapan penelitian, yaitu reflektor radiasi panas de $\mathrm{Engan}$ satu baris sirip.

\section{METODE PENELITIAN}

\section{Pembakaran LPG}

Proses pembakaran akan terjadi jika unsur-unsur bahan bakar teroksidasi. LPG untuk rumah tangga, adalah campuran dari $50 \%$ gas propana $\left(\mathrm{C}_{3} \mathrm{H}_{8}\right)$ dan $50 \%$ gas butana $\left(\mathrm{C}_{4} \mathrm{H}_{10}\right)$, sehingga jika direaksikan menjadi:

$$
\begin{aligned}
& \mathrm{C}_{7} \mathrm{H}_{18}+11.5 \mathrm{O}_{2}+43.24 \mathrm{~N}_{2} \rightarrow \\
& 7 \mathrm{CO}_{2}+9 \mathrm{H}_{2} \mathrm{O}+43.24 \mathrm{~N}_{2}
\end{aligned}
$$

\section{Daya Kompor}

Hasil pengujian daya digunakan untuk menentukan diameter panci yang digunakan. Ukuran panci dipilih berdasarkan daya maksimum kompor, perbandingan daya maksimum dan luas permukaan $7 \mathrm{~W} / \mathrm{m}^{2}$. Sedangkan volume air yang digunakan untuk pengujian efisiensi uji air mendidih (Boiling water test) adalah 2/3 dari volume panci [15].

\section{Efisiensi Kompor}

Pengujian efisiensi termal kompor LPG, dilakukan menurut Standar India (IS) 4246: 2002 yaitu dengan uji air mendidih (boiling water test) [3]. Proses pengujian ditunjukkan pada Gambar 1. Pada pengujian ini air dipanaskan dari suhu awal (Ta) ke titik didih (Td), dan setelah air mendidih pemanasan dilanjutkan hingga mencapai total waktu satu jam (Ts). Lihat gambar 1.

Efisiensi kompor dapat dihitung dengan rumus [8]:

$$
\eta_{o v}=\frac{\left\{\left(m_{w} \cdot C_{p w}\right)+\left(m_{b} \cdot C_{p b}\right)\right\} x\left(T_{2}-T_{1}\right)+m_{u} \cdot H}{m_{f} \cdot E}
$$

Dimana:

$$
\begin{aligned}
& \text { nov : efisiensi overall (\%) } \\
& \mathrm{Qu}_{\mathrm{u}} \quad \text { : panas berguna }(\mathrm{kJ} / \mathrm{dt}) \\
& m_{w} \quad: \text { masa air }(\mathrm{kg}) \\
& C_{p w} \quad: \text { panas spesifik air }(\mathrm{kJ} / \mathrm{kg} \mathrm{K}) \\
& \mathrm{m}_{b} \quad \text { : masa panci }(\mathrm{kg}) \\
& C_{p b} \quad: \text { panas spesifik panci }(\mathrm{kJ} / \mathrm{kg} \mathrm{K}) \\
& T_{1} \quad \text { : temperatur awal air (K) } \\
& T_{2} \quad: \text { temperatur air mendidih (K) } \\
& m_{u} \quad \text { : masa uap }(\mathrm{kg}) \\
& m_{f} \quad: \text { masa bahan bakar terpakai }(\mathrm{kg}) \\
& \text { nilai kalor netto bahan bakar } \\
& \mathrm{LPG}(\mathrm{kJ} / \mathrm{kg}) \\
& H \quad \text { : panas laten air menguap }(\mathrm{kJ} / \\
& \mathrm{kg} \text { ) }
\end{aligned}
$$

\section{Spesikasi Bahan Penelitian}

Bahan dan peralatan yang digunakan dalam penelitian ini antara lain: kompor LPG satu tungku, SNI 7368-2001; tabung gas LPG 3 kg; bahan bakar LPG Pertamina; panci aluminium; stopwatch dan thermometer air; timbangan duduk digital 0,1 gr; gelas ukur; reflektor radiasi panas bersirip 1) tinggi $30 \mathrm{~mm}$ dengan sudut $22,5^{\circ}$, dimensi sirip tetap, yaitu lebar $20 \mathrm{~mm}$ dan tinggi $5 \mathrm{~mm}$, (2) variasi baris sirip 1 baris, 2 baris, dan 3 baris, (3) material reflektor stainless steel; data loggerl akuisisi; flow meter, kamera; dan air. 
Model reflektor radiasi panas bersirip

Reflektor dibuat dari stainless steel berbentuk kerucut terpotong menghadap keatas, yaitu diameter atas lebih besar dari diameter bawah. Pada sisi bagian dalam diberi sirip-sirip berbentuk segi empat dengan dimensi yang sama. Sirip-sirip dibuat dengan cara memotong sisi plat reflektor pada rusuk kanan, kiri dan bawah dari masing-masing sirip serta diangkat dengan sudut tertentu, sehingga tidak menambahkan material eksternal. Desain reflektor ditunjukkan pada Gambar 2.

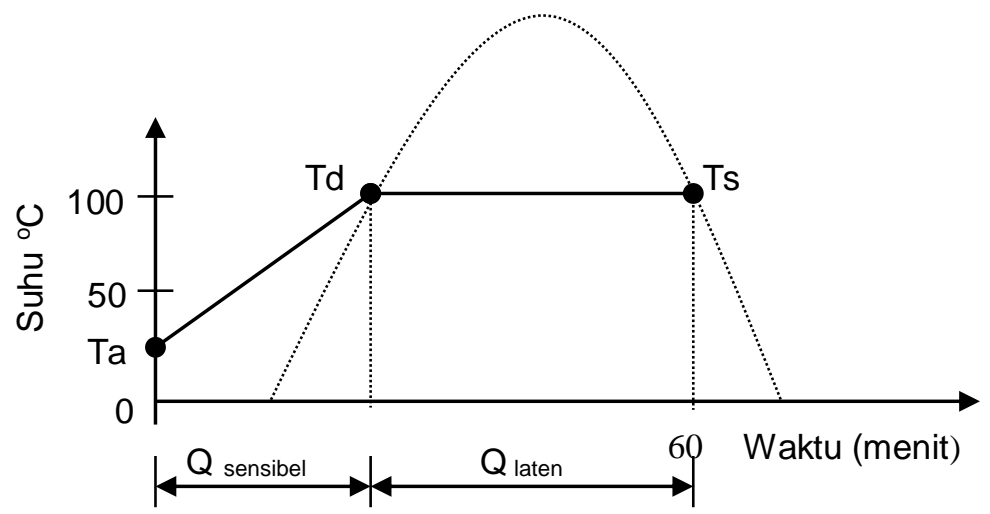

Gambar 1. Perubahan suhu terhadap waktu selama pengujian
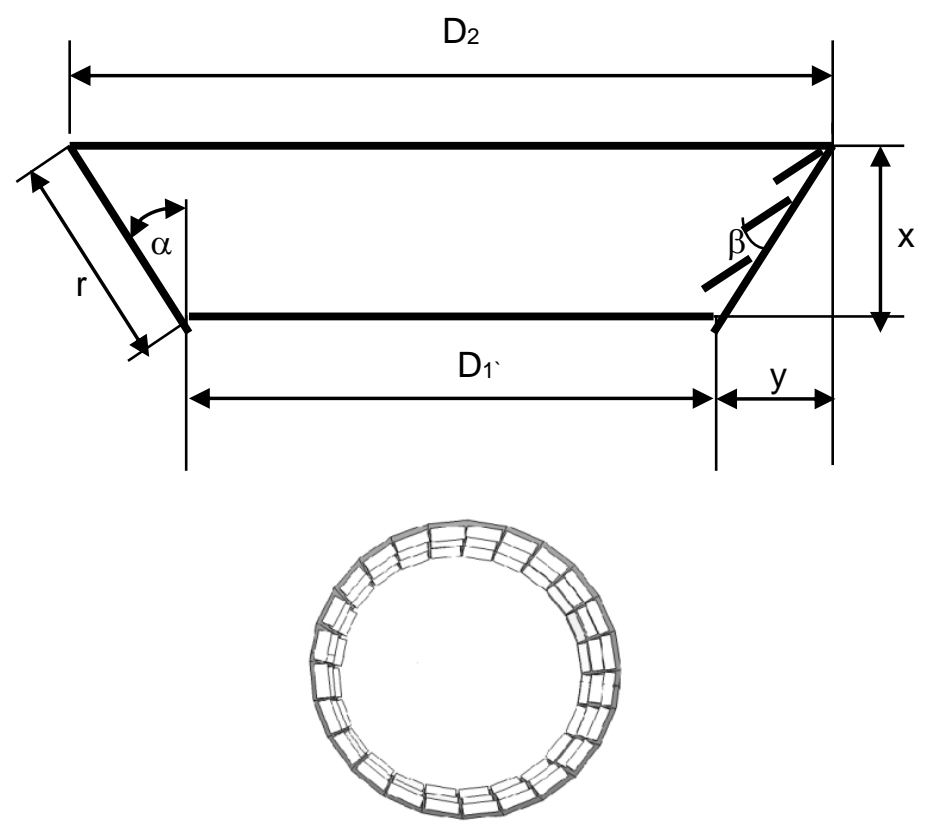

Gambar 2. Desain reflektor bersirip 


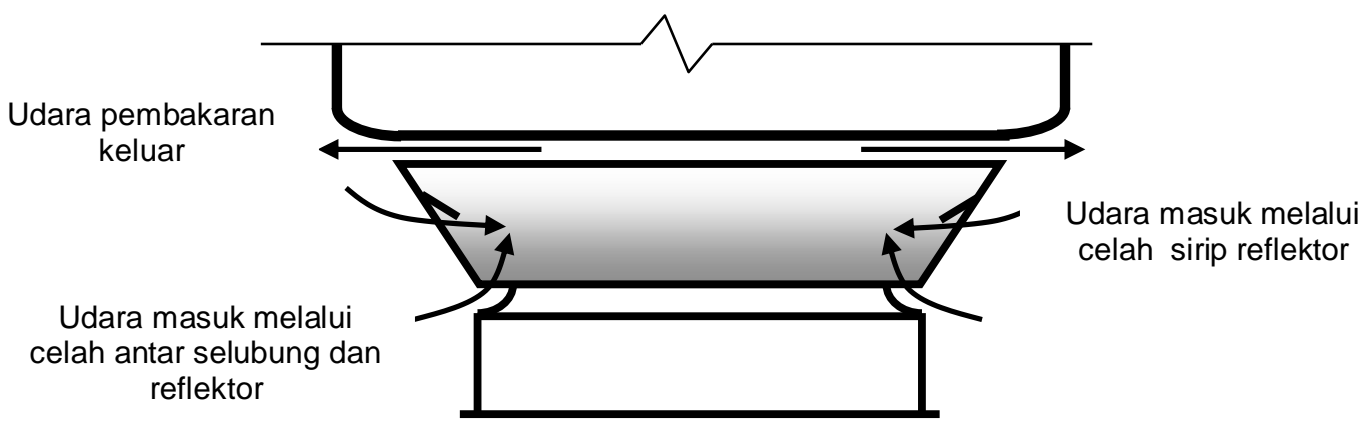

Gambar 3. Pemasangan reflektor bersirip

\section{Pemasangan reflektor bersirip}

Reflektor dipasang antara keluaran api (burner) dengan beban (load). Diameter reflektor lebih besar dari diameter api kompor sehingga ada jarak antara api dengan reflektor. Cara ini dilakukan agar tidak ada api yang langsung mengenai permukaan reflektor yang dapat mengganggu fungsi reflektor. Pemasangan reflektor dan sketsa lintasan udara pembakaran sekunder ditunjukkan pada Gambar 3.

\section{Urutan Pengujian}

a. Pengujian daya

Untuk menghitung besarnya daya kompor harus diketahui besarnya jumlah konsumsi bahan bakar, untuk itu diperlukan pengujian konsumsi bahan bakar. Daya kompor yang diperoleh dari hasil perhitungan selanjutnya digunakan untuk menentukan besarnya diameter panci.

b. Pengujian konsumsi bahan bakar dan produksi uap

Data yang diperoleh dari pengujian konsumsi bahan bakar dan produksi uap dipergunakan untuk menentukan besarnya efisiensi kompor. Pengujian efisiensi dilakukan dengan cara mengkomparasikan antara tanpa menggunakan reflektor, reflektor tanpa sirip dan dengan reflektor bersirip. Pengujian untuk menentukan efisiensi kompor dilakukan dengan uji air mendidih (boilling water test).

\section{c. Pengujian distribusi temperatur api}

Pengujian ini dimaksudkan untuk mendapatkan gambaran contour distribusi temperatur isothermal api. Hal ini untuk memperoleh kesimpulan yang lebih kuat tentang pengaruh penggunaan alat ini terhadap peningkatan efisiensi kompor LPG.

Pengujian dilakukan pada kompor dengan beban tanpa menggunakan reflektor, menggunakan reflektor tanpa sirip, dan dengan menggunakan reflektor bersirip. Proses pengolahan data akan dilakukan dengan menggunakan program matlab.

\section{HASIL DAN PEMBAHASAN}

Pengujian daya kompor

Berdasarkan hasil analisa data, diperoleh daya untuk kompor LPG sesuai SNI 7368-2007 sebesar 1,7106 KW. Berdasarkan daya kompor tersebut maka diameter panci yang digunakan, yaitu sebesar $220 \mathrm{~mm}$ dengan masa air $( \pm 2 / 3$ volume bejana) sebesar 3625 gr [15].

\section{Pengujian konsumsi bahan bakar dan produksi uap}

Data hasil pengujian konsumsi bahan bakar dan produksi uap digunakan untuk menentukan efisiensi kompor gas LPG. Dengan daya sebesar $1,7106 \mathrm{KW}$, diameter bejana $220 \mathrm{~mm}$, dan masa air $3625 \mathrm{gr}$ maka diperoleh data sebagai berikut: 


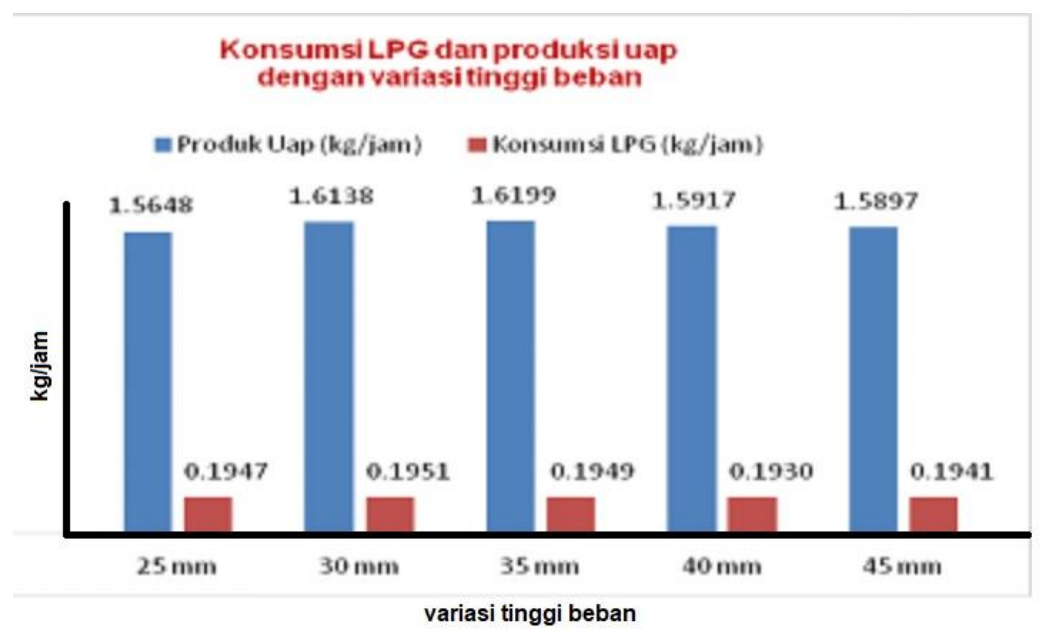

(a)

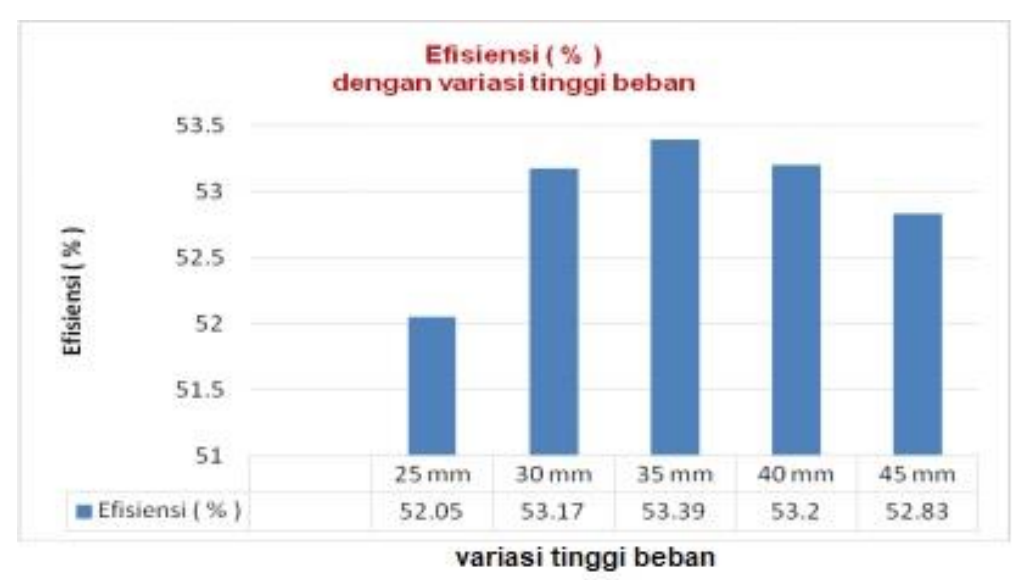

(b)

Gambar 4. (a) Diagram konsumsi bahan bakar dan produksi uap hasil pengujian variasi tinggi beban tanpa reflektor (b) Diagram efisiensi hasil pengujian variasi tinggi beban tanpa reflektor

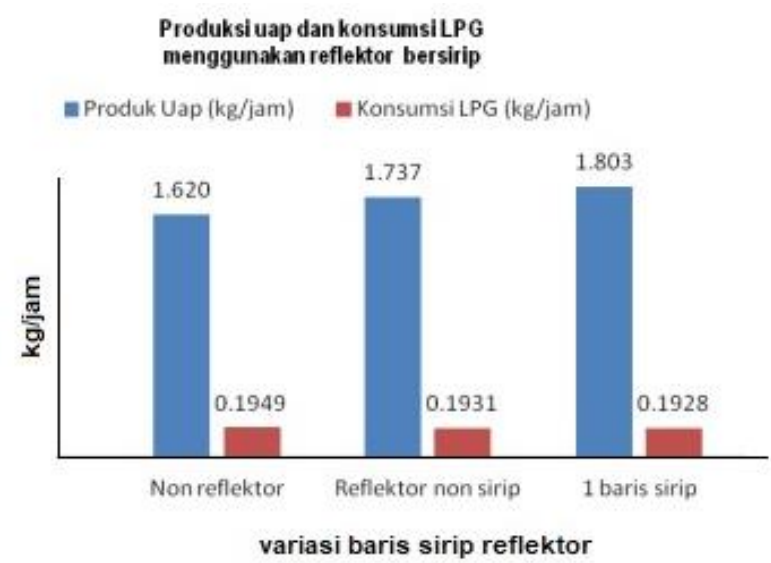

(a) 


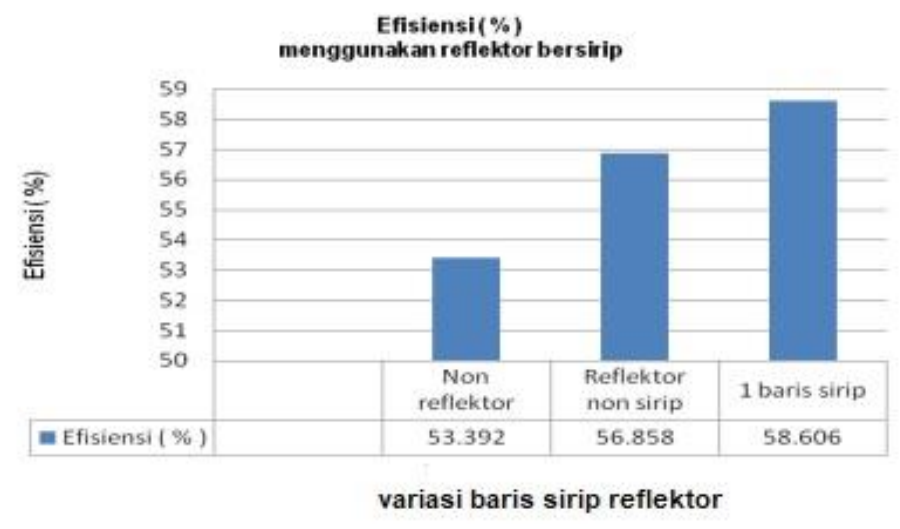

(b)

Gambar 5. (a) Diagram konsumsi bahan bakar dan produksi uap hasil pengujian dengan variasi baris sirip reflektor (b) Diagram efisiensi hasil pengujian dengan variasi baris sirip reflektor

1. Pengujian dengan variasi tinggi beban tanpa reflektor

Pengujian ini dilakukan untuk mendapatkan tinggi beban optimal pada kompor LPG. Berdasarkan grafik pada Gambar 4 terlihat bahwa tinggi beban 35 $\mathrm{mm}$ memberikan efisiensi tertinggi yaitu 53.39\% [10]. Tinggi beban optimal tersebut, dijadikan acuan untuk pengambilan data pada pengujian berikutnya.

\section{Pengujian dengan variasi baris sirip reflektor}

Berdasarkan diagram pada gambar 5 terlihat bahwa produksi uap terus mengalami peningkatan mulai dari kompor tanpa reflektor, reflektor tanpa sirip, dan reflektor dengan 1 baris sirip. Sedangkan konsumsi bahan bakar terus mengalami penurunan mulai dari kompor tanpa reflektor, reflektor tanpa sirip, dan reflektor dengan 1 baris sirip.

Efisiensi berbanding lurus dengan produksi uap dan berbanding terbalik dengan konsumsi bahan bakar. Berdasarkan diagram pada Gambar 5 terlihat bahwa efisiensi meningkat dengan penggunaan reflektor bersirip. Efisiensi tertinggi terjadi pada penggunaan reflektor 1 baris sirip.

Konsumsi bahan bakar tertinggi terjadi pada kompor LPG tanpa reflektor sebesar $1949 \mathrm{gr} / \mathrm{jam}$ dan terendah pada penggunaan reflektor 1 baris sirip sebesar $1929 \mathrm{gr} / \mathrm{jam}$. Terjadinya penurunan konsumsi bahan bakar disebabkan oleh perbaikan proses pembakaran. Dengan pembakaran yang sempurna maka penyerapan panas oleh beban terjadi secara optimal. Hal ini terjadi karena refleksi panas dari reflektor bersirip ke ruang bakar membantu membakar sisa uap bahan bakar yang belum terbakar pada daerah pembakaran. Akibatnya luas area api dewasa pada daerah pembakaran semakin meningkat, sehingga panas berguna yang diserap oleh beban juga meningkat. Dengan meningkatnya penyerapan panas berguna oleh beban maka meningkat pula produksi uap yang dihasilkan. Hal inilah yang menyebabkan optimalnya efisiensi pada penggunaan reflektor bersirip.

Untuk kompor tanpa reflektor dibandingkan dengan kompor yang menggunakan reflektor tanpa sirip, terjadi penurunan konsumsi bahan bakar yang cukup besar yaitu $1.8 \mathrm{gr} / \mathrm{jam}$ dan kenaikkan produksi uap yang cukup besar pula yaitu $117 \mathrm{gr} / \mathrm{jam}$. Hal ini menyebabkan terjadinya kenaikkan efisiensi yang cukup signifikan sebesar $3.47 \%$. Kenaikan efisiensi terjadi karena dengan penggunaan reflektor non sirip, mampu merefleksikan kembali losses panas yang terjadi. Refleksi panas dari reflektor ke daerah pembakaran, membantu membakar uap bahan bakar 
yang belum terbakar pada daerah pembakaran. Proses tersebut menjadikan pembakaran lebih sempurna dengan luas area panas yang meningkat.

Untuk reflektor non sirip ke 1 baris sirip konsumsi bahan bakar terjadi penurunan yang relatif kecil, sebesar 0,3 gr/jam namun produksi uap meningkat sebesar $66 \mathrm{gr} / \mathrm{jam}$, sehingga menjadikan efisiensi meningkat sebesar $1,75 \%$.

Efisiensi tertinggi terjadi pada penggunaan reflektor 1 baris sirip, dengan peningkatan sebesar 5,21\% jika dibandingkan dengan tanpa menggunakan reflektor dan sebesar 1,75\% jika dibandingkan dengan penggunaan reflektor non sirip. Peningkatan tersebut terjadi karena dengan penggunaan reflektor bersirip, dapat menangkap dan merefleksikan lebih optimal losses panas radiasi yang terjadi. Hal ini mengingat bahwa refleksi radiasi bersifat difusi, sehingga dengan reflektor tanpa sirip masih banyak losses panas yang terjadi. Keberadaan celah atau lubang di bawah sirip membantu supply oksigen natural ke daerah pembakaran, sehingga menjadikan pembakaran lebih sempurna. Efek refleksi panas dari reflektor ke daerah pembakaran, membantu membakar uap bahan bakar yang belum terbakar pada daerah pembakaran.

Pengujian distribusi temperatur api kompor $L P G$

Pengujian ini diperlukan untuk mengetahui pengaruh pemasangan reflektor radiasi panas bersirip terhadap contour distribusi temperatur isothermal api. Hasil yang diperoleh digunakan untuk memastikan dampak positip yang ditimbulkan oleh pemasangan reflektor radiasi panas bersirip tersebut. Berdasarkan hasil pengujian diperoleh data sebagai berikut:

1. Distribusi temperatur api kompor LPG tanpa beban

Berdasarkan contour distribusi temperatur isothermal kompor tanpa beban terlihat bahwa kompor tanpa reflektor, temperatur tinggi rata-rata cukup rendah dengan distribusi temperatur tinggi yang menyebar. Berdasarkan degradasi warna contour distribusi, bahwa penambahan reflektor bersirip, menjadikan distribusi temperatur tinggi lebih fokus dengan luas area temperatur tinggi yang lebih luas. Sebagaimana ditunjukkan pada Gambar 6.

2. Distribusi temperatur api kompor LPG dengan beban

Berdasarkan contour distribusi temperatur isothermal kompor dengan beban terlihat bahwa kompor tanpa reflektor, menghasilkan temperatur tinggi rata-rata yang relatif rendah dengan luas area distribusi temperatur tinggi yang relatif kecil. Berdasarkan degradasi warna contour distribusi temperatur, bahwa penambahan reflektor bersirip, menjadikan distribusi luas area temperatur tinggi yang lebih luas. Dengan reflektor 1 baris sirip, degradasi warna merah yang menunjukkan luas area temperatur tinggi semakin luas. Dengan luas area panas yang semakin luas maka sentuhan luas area panas dengan beban juga semakin luas, yang akan memberi dampak terhadap penyerapan energi yang semakin besar oleh beban. 

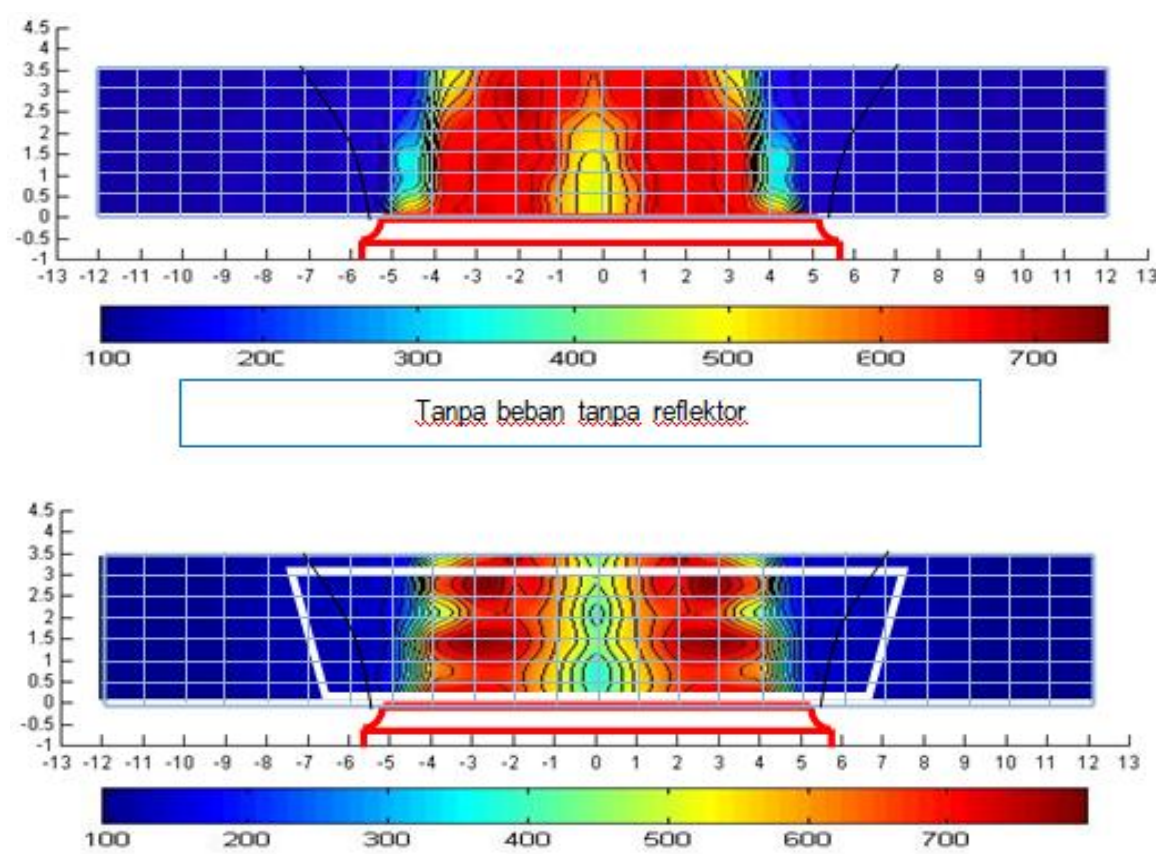

Tanpa beban dengan reflektor 1 baris sirip dengan beban.

Gambar 6. Distribusi temperatur api tanpa beban
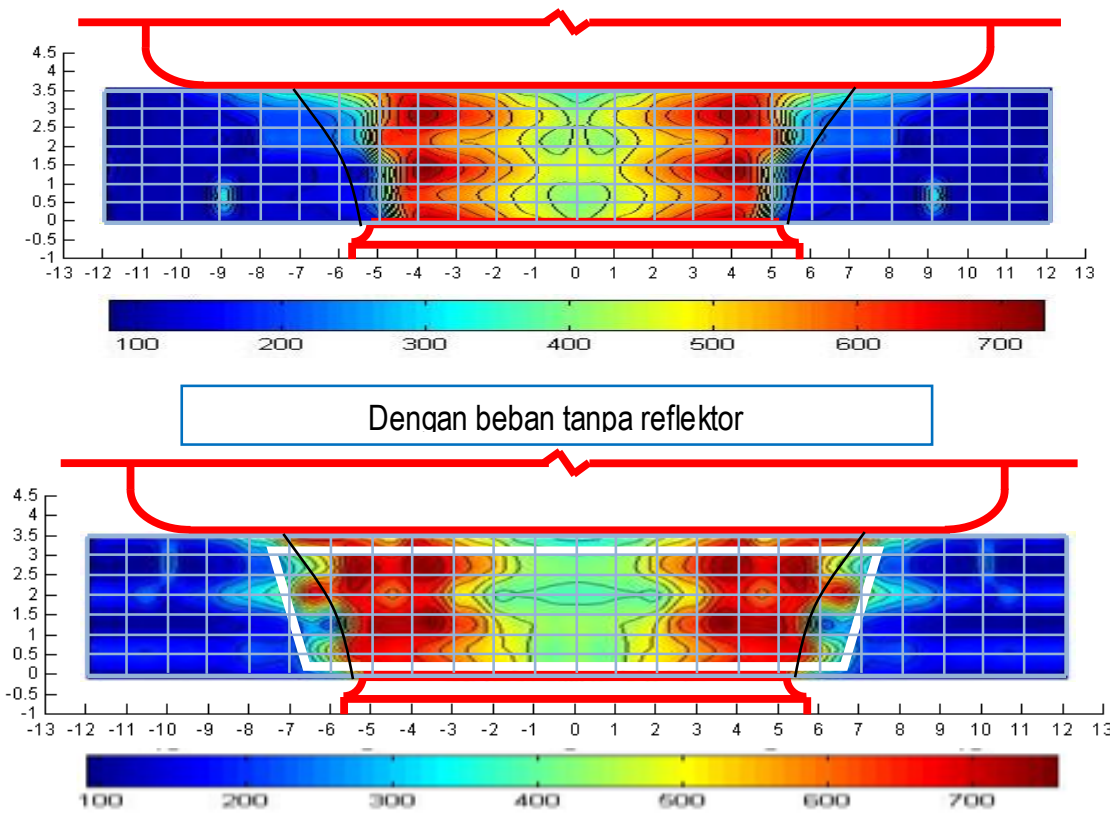

Reflektor 1 baris sirip dengan beban

Gambar 7. Distribusi temperatur api dengan beban 


\section{KESIMPULAN}

Penggunaan reflektor radiasi panas dengan 1 baris sirip pada kompor LPG mampu meningkatkan efisiensi. Efisiensi yang dicapai sebesar 58,61\%, meningkat 5,21\% jika dibandingkan dengan kompor LPG tanpa reflektor dan 1,75\% jika dibandingkan dengan penggunaan reflektor tanpa sirip.

Dengan penggunaan reflektor radiasi panas bersirip mampu meningkatkan luas area api dewasa (titik dimana bahan bakar habis terbakar). Kondisi tersebut menyebabkan sentuhan area panas dengan beban semakin meluas, sehingga penyerapan panas oleh beban juga meningkat.

\section{DAFTAR PUSTAKA}

[1] Dongbin. Z., Jinsheng, L., Guangchuan, L.,Yan, D., Gang. X. and Lihua L., 2007, Effects on Combustion of Liquefied Petroleum Gas of Porous Ceramic Doped With Rare Earth Elements. Journal of Rare Earths. 25: 4-7.

[2] ESDM, 2013, Konversi Mitan ke LPG Hemat $R p \quad 70$ Triliun, http://www.esdm.go.id/berita/migas/40mig as/6513-konversi-mitan-ke-lpg-hemat-rp70-triliun.html. (diakses 10 Oktober 2016.

[3] Gohil, P., Channiwala, 2011, Experimental Investigation of Performance of Conventional Lpg Cooking Stove, Fundamental J. Thermal Science and Engineering, 1 (1): 25-34.

[4] Holman, J.P. 2002, Heat Transfer, sixth edition, Southern Methodist University: Mc Graw-Hill.Ltd.

[5] Incropera, Frank P., David P. De Witt. 1990. Fundamentals of Heat and Mass Transfer, third edition. New York: John Willey \& Sons. Inc.

[6] Khan, M.Y., Saxena, A. 2013. Performance of LPG Cooking Stove Using Different Design of Burner Heads, International Journal of Engineering Research \& Technology (IJERT), 2 (7): 656-659..

[7] Mishra, N., Mishra, S., Muthukumar,P., 2015, Performance Characterization of $A$ Medium-Scale Liquefied PetroleumGas Cooking Stove With A Two-Layer Porous Radiant Burner, Journals Applied Thermal Engineering. 89 (10): 44-50.
[8] Muthukumar, P., Shyamkumar, P., 2013, Development of Novel Porous Radiant Burners For LPG Cooking Applications, Journals Fuel, 112: 562566.

[9] Pallawagau, La P, 1989, Pengujian Daya dan Efisiensi Kompor Minyak Tanah Bersumbu, Journal LEMIGAS.

[10] Sudarno, Fadelan, 2016, Peningkatan Efisiensi Kompor LPG dengan Menggunakan Elemen Bara Api, Jurnal Semesta Teknika. 19 (2): 165175.

[11] Sumadijono, P.A., 2003, Pengaruh Sudut Reflektor Panas Terhdap Efisiensi Kompor Sumbu Standart, Thesis, Tidak dipublikasikan. Surabaya: Institut Teknologi Sepuluh Nopember Surabaya.

[12] Supono, 2014, Mengenal Lebih Dekat LPG (Liquified Petroleum Gas) sebagai Bahan Bakar untuk Kompor Gas,

http://www.vedcmalang.com/pppptkbo emlg/index.php/menuutama/departem en-bangunan-30/1131-supono1. (diakses 8 Mei 2017).

[13] Syarial, M. 2012, Unjuk Kerja Kompor Berbahan Bakar Biogas Efisiensi Tinggi Dengan Penambahan Reflektor, Skripsi. Tidak dipublikasikan, Surabaya: Institut Teknologi Sepuluh Nopember Surabaya.

[14] Turns Stephen, R., 1996, An Intruduction to Combustion, Concepts and Application, Southern Methodist University: Mc GrawHill.Ltd.

[15] VITA, 1985, Testing the Efficiency of Wood-burning Cookstove International Standards, Revised May.

[16] Wardani, D., 2007. Alat Penghemat Bahan Bakar Gas Pada Kompor Gas Rumah Tangga, Skripsi. Tidak dipublikasikan, Bandung: Institut Teknologi Bandung.

[17] Widodo, A. S., 2014, Selubung Radiasi untuk Efisiensi Penggunaan Energi pada Kompor Gas, Jurnal Rekayasa Mesin. 3 (3): 291-295. 
[18] Widodo, A. S., 2015, Jarak Optimum Panci Terhadap Selubung Pada Efisiensi Sistem Pemanasan Air, Jurnal Rekayasa Mesin. 6 (1): 69-73.

[19] Widodo, A. S., 2016. Peningkatan Efisiensi Sistem Pemanasan dengan Penambahan Grid pada Perforated Burner, Jurnal Rekayasa Mesin. 7 (1): 21-25.
[20] World Bank, Energy Department. 1985. Test Results on Kerosene and Others Stoves for Developping Countries, America: Washington. 